\title{
Globalization and Culture: A Sociolinguistics Study
}

\author{
Md Zahidul Islam \\ Assistant Professor \\ Department of English \\ Bangladesh Islami University, Dhaka-I2I4, Bangladesh \\ E-mail: zahid_iuk@yahoo.com
}

\begin{abstract}
A significance feature of globalization is the transaction of ideas as indicated by internet. The concern engages the clash of cultures and the spread of acquisitive values. This has enormous influence on hoe people think, act or behave. The values that this entertainment industry reflects often promote materialism, violence and immorality. Hence, this paper examines the concept of globalization and culture as well as the study of sociolinguistics. It also scans the impact of globalization on culture. Since the turn of the Millennium, globalization has become a major focus in sociolinguistics and discourse analysis, investigating themes such as: learning and teaching in diverse urban classrooms (Spotti, 20I I; Karrebæk, 2012) complementary education (Blackledge \& Creese, 2010); internationalisation in higher education (Piller \& Cho, 2013) mass media and the internet (Androutsopoulos, 2007; Varis \& Wang, 20II) popular culture and advertising (Jacquemet, 2005; Kasanga, 20I0) hip-hop and graffiti (Pennycook, 2007) language vitality (Vigouroux \& Mufwene, 2008) travel and tourism (Jaworski \& Thurlow, 20I0) migration and asylum seekers (Vigouroux, 2008; Dong, 20I I; Maryns, 2006) the new globalised economy (Block, 2012; Heller, 2003) and long-distance financial fraud (Blommaert \& Omoniyi, 2006). Papers in Coupland (2003, 2010) and such monographs as (Fairclough, 2006; Blommaert, 2010; Heller, 20I I) among others, have attempted general statements outlining a sociolinguistics of globalization.
\end{abstract}

Keywords: Critical Thinking, EFL, Reading Comprehension, Storytelling.

\section{Introduction}

Science and technology now has created the possibility and even the likelihood of global culture. The fax machine, satellite and cable TV have swept away the national cultural boundaries. Duru-Ford (2002) opines that global entertainment companies shape understanding and dreams of ordinaries citizens wherever they live. The local culture are inevitably falling victim to global "consumer" culture. For instance, English Language, as observe by (Tukus-Dubrow, 2002) is gradually but steadily eradicating the local dialect while consumer values according to (Duru-Ford, 2002) are overwhelming people's sense of community and social solidarity.

For instance, globalization has increasingly knitted together the world created unity out of great diversity. Jeans (2002) noted that Coca Cola, Disney and McDonald symbolize the process along with Sony. Shell oil and IBM to influence global consumer's taste. There are known and consumed all over the world. In addition, they are powerful companies that drive globalization forward, creating new laws, new business process, new ways to eat and drink new hopes and dreams.

Fridah (2002) observes that there are optimists and pessimists, who have contradicting views. She states that optimists look forward to global village linked altogether by internet, and benefiting from over-increasing material well-being. On the other hand are pessimists seeing a frightful corporate tyranny destroying the environment and culture, and sweeping away all that is healthy and meaningful for human existence? Probably this is why (Willien, 2002) predicts deterritorialization which he describes or calls the end of geography and the end of sovereignty. This paper therefore examines the concept of globalization and culture as well as the impact of globalization on the culture.

\section{Literature Review}

Wardhaugh and Thanasoulas each define language in a somewhat different way, with the former explaining it for what it does, and the latter viewing it as it relates to culture. Wardhaugh (2002, p. 2) defines language to be: a knowledge of rules and principles and of the ways of saying and doing things with sounds, words, and sentences rather than just knowledge of specific sounds, words, and sentences.

While Wardhaugh does not mention culture per se, the speech acts we perform are inevitably connected with the environment they are performed in, and therefore he appears to define language with consideration for context, something (Thanasoulas, 200I) more directly compiled in the following: (language does not exist apart from culture, that is, from the 
socially inherited assemblage of practices and beliefs that determines the texture of our lives (Sapir, 1970, p. 207). In a sense, it is 'a key to the cultural past of a society' (Salzmann, I998, p. 4I) a guide to 'social reality' (Sapir, I929, p. 209, cited in Salzmann, I998, p. 4I).

And if we are to discuss an association between globalization and culture, we must also have some understanding of what culture refers to. Good enough (I957, p. I67) taken from (Wardhaugh, 2002, p. 219) explains culture in terms of the participatory responsibilities of its members. He states that a global culture is made up of whatever it is one has to know or believe in order to operate in a manner acceptable to its members, and to do so in any role that they accept for any one of themselves.

Malinowski (Stern, 2009) views culture through a somewhat more interactive design, stating that it is a response to need, and believes that what constitutes a culture is its response to three sets of needs: the basic needs of the individual, the instrumental needs of the society, and the symbolic and integrative needs of both the individual and the society.

\section{Objectives of the Research}

The main objectives of the study are as follow:

- To explore the global-culture relationship in the context of sociolinguistics

- To recognize human's cognitive processes

- To cram society and man's position in global-culture

- To reflect the necessity for sociolinguistics and cultural proficiency

- To show the gender-related language variation

\section{Research Methodology}

The research is based on secondary sources of data. The information has been collected from library, facts, textbooks, journals, reports and other internet sources to depict the results. All the data are studied sincerely to achieve the objectives of the study.

\section{Data Analysis \\ 5.I Concept of Globalization}

Globalization has become one of the most popular buzzwords of our time frequently used by people. Globalization is the increasing interaction of national economy with that of the First World, which ultimately aims at creating a state of frictionless capitalism. According to (Orunmoluyi, 2002) it is a process of creating a global market in which increasingly all nations are forced to participate. The process of globalization entails that there is interconnection of sovereign nations through trade and capital flows; harmonization of economy rules that govern relationship among these sovereign nation; creating structures to support and facilitate interdependent and creating a global market place.

From the culture point of view, (David, 2002) state that globalization is the process of harmonizing different culture and beliefs. Castells (1997) state that globalization is the process that eroding differences in culture and producing a seamless global system of culture and economic values. The harmonization, according to (Awake, 2002) his achieved too due to advancement in communication and countries are increasingly being forced to participate. Therefore, globalization can be viewed as a process of shifting autonomous economies into a global market. In other words, it is the systematic integration of autonomous economies into a global system of production and distribution.

The consequent is that the word of separate nation-states is said to be ending if the process of globalization is allowed to run its logical course. The new technology, based on the computer and satellite communication have indeed revolutionized our traditional conception of the media, both print and electronic. Books, newspapers, radio, television and video program are now being transposed into the multimedia world of the cyber space and available to all people of the world wherever they may live.

\subsection{Concept of Culture}

Culture is a set of norms that set standards for a society of what is acceptable behavior. In every culture there are basic standards for social interaction such as personal space distance, eye contact, amount of body language displayed in public, negotiating style, etc. Culture has also been defined differently by people. The different definitions attach to culture is based on the differences in the orientation of the people. According (Ekeh, 1989) culture is constructing used in an attempt to analyze and integrate events and ideas in broad spectrum of areas of society. Jekayinfa (2002) states that from wider perspective, culture includes the total repertoire of human action which are socially transmitted from generation to generation. Tyler (I87I) in (Jekayinfa, 2002) views culture as configuration of institutions and modes of life. Furthermore, he states that culture is the complex while which includes knowledge, belief, arts, morals, laws, customs, and any other capabilities and habits acquired by man as member of the society. Among the feature that characterize culture is that has its own personality and identity. The fact that we are human does not mean we are the same. However, it is noted that every moment, we are being transformed, always growing like the cell in our 
bodies. Culture changes exactly the same way as the human being change. In other words, culture is dynamic. According to (Odiora, 2002) the transformation of culture is gradual and not sudden. Obiora (2002) contends that culture is a continuous process of change. In spite of the change culture continues to give a community a sense of dignity, continuity, security and binds society together. Another attribute of culture is that it is learned, acquired, transmitted or diffused through contact or other means of communication flow from one generation to another. For instance, in the old days a young Nigerian Girl from Yoruba culture would knee down to greet their elders. For the Britain a Girl may stretch hand shake.

In the modern day third world countries, absolute kneeing down may be fading as noted by (Tardif, 2002) opines that culture is not genetically transmitted rather it takes place by process of absorption from the social environment or through deliberate instruction. This is to say that culture is learned. Such learning does not occur through natural inheritance. Probably that is why Jekayinfa (2002) maintains that the man learns culture through the process of socialization, enumeration, personal experience and through deliberate induction nation or teaching. It should be noted that learning of culture is a lifelong process. That is, learning of culture is from birth of death. Jekayinfa (2002) further observes that what is learnt differ from society to society and from one stage to another. However, all that is learnt is geared towards the realization of the goal of the society.

\subsection{Impact of Globalization on Culture}

The continuing world-wide growth of access to internet is being mirrored by an equally discernible rise in its use by ethnic ideological and national groups anxious to assert their culture identity (Obiora, 2002). This is most apparent in the information obtain some of which reflect interest and goals. With trade agreement and liberalization of telecommunications, (Corbit, I99) notes that corporate culture is said to rule the nation (Jean, 2002) observes that globalization has made it possible for the whole world to be wired and plugged into T.V program, movies, news, music, life style and entertainment of the advance countries. Satellite, cables, phones, walkmans, V.C.Ds, D.V.Ds and retails grants as well as wonders of entertainment technology are creating the mass marketing of culture. The impact of globalization on the culture is immense and diverse. It has affected the cultural aspect of people in different ways. For instance, the loud echoing advertisement rhythms of the famous Coca-Cola drinks can be heard across the boundaries in towns, cities and even in remote rural areas where drinking water is hard to get. This is why (Duru-Ford, 2002) observes that people had to change their living ways due to influence of globalization.

Since globalization involves the opening up the economics and knowledge freely and widely to the global market and its forces, (Friday, 2002) contends that it is required that whatever the nature of their economics, knowledge their level of the development and whatever their location in the global economy, all countries must pursue a common set of economic policies. Of particular importance, they must permit free and discriminate operation of transnational corporation in their economies, open their economies freely and indiscriminately to import and concentrate on exporting what they are supposed to be good at; reduce the role of government in the economy to that of supporting the market and private enterprises; and leave the determination of prices of goods, currencies labor, as well as the allocation of the resources to the operation of the market (Awake, 2002).

Tuhus-Dubrow (2002) has observe that a language is considered endangered when it is no longer spoken by children, moribund by only handful of elderly speaker and left to extinct when it is no longer spoken. The number of language endangered varies but the average estimates from studies, according to (Whalen, 2002) are alarming with half of the world language struggling to survive. It is opinion of (Walleh, 2002) that a language should be preserved. This is because language recognizes people's right to determination of their own fate. Any culture can be expressed in any language in some ways, but the nature language is most effective.

For huge advancement of globalization, language is also influenced and it plays role to change the total shape of language. Suppose, in Nigeria, the indigenous languages are rendered impotent because, English Language is the official language of the country. Globalization has made English language a predator language. This informs (James, I997) to state that English language is a "killer" language. English language has run rampant all over Nigeria. People want to speak English language because it is the language of advertising, block buster, movies and pop music, as well as vital tool of success. English language has become certainly the most successful lingua franca we have ever seen. Wade (1997) maintains that we will continue to use languages of our but we all know that these languages are giving way to English language.

Global communication according to (Oni, 200I) is observed to the flattening the cultural terrain in the direction of the dominance of the modes and material practices of the global economic leaders, most particularly in the United States of America (USA). The ownership of the strategic components of the global communication technology's i.e. Microsoft, is seen as determining element in this flattening of terrain. Today, the world is moving towards the extinction of a rich and varied cultural and symbolic life and emerging in the global language. Cyrstal (1997) notes that English Language that is emerging as global language is no longer under the control of its original owners. On the other hand, the Nigerian indigenous languages are facing serious danger of extinction. The effect of globalization, the worldly people are also affected devastatingly. The same country which is earlier mentioned has become the field of AIDS, Orphas, land mines, war and drought and music has been neutralized 
with the western beats of Michael Jackson, Lionel Richie, Craig-David etc. Many Youths here now prefer western hair style, shoes and dressing.

Yakubu (I999) discovers that young people of the Third World countries are the largest consumers of global culture. With MTV, Euro star global entertainment is signalling absolute dominance of the music of western culture. Probably that is why Jean 2002 maintains that TV does not offer only entertainment it embodies the sheer power and influence of the global corporate culture. Television has become the agent of the new global corporate vision.

All over the world, people of all ages are exposed to the same music, the same sporting events, the same news, soapopera and the same glamorous life style. 'It is observed that the culture of U.S. is available everywhere (PIPA, I999). Satellite T.V. has made T.V. program to be available for 24 hours.

Yakubu (1999) notes that about 75\% of the world population has access to daily T.V. reception. Most of the T.V. screens are dominated by U.S. films, music and life style. Children no longer sit in the evening for tales by moonlight that promote the values of respect, integrity, peace, love and unity. Even, it has been neglected in the rural areas where this sort of environment would fit best. The struggle now is for survival; how to get a bond of meal to fill family. Children now involve themselves in crime such as robbery, violence and female prostitution.

Fridah (2002) notes that in the olden days, most communities in Africa had a strong policy of food security. Distant family compound. Today, all these have vanished and people have been forced into a situation where they are living from hand to mouth. Globalization has made the working class run into the habit of borrowing teir salaries even before they receive them. According to (Oni, 200I) bribery and corruption are encouraged so as to make ends meet.

Awareness of globalization is on the increase that no one wants to be left behind. Women, in Nigeria have realized this probably, that is why (Obwra, 2002) maintains that women economic activities have been highly affected y globalization. Women are now forced to enter into those economic exclusively preserved for men. Globalization has exposed the women into crime and other illegal economic activities.

Globalization has resulted in the introduction of policies aimed at eliminating all obstacles of the "free" exercise of economic activity across boundaries including trade liberalization, tederegulation of production, the labor market and the market of goods and services and the implementation of regional and international agreements. Nigeria, for instance, has opened her border to goods and services of ECOWAS nations. Furthermore, Nigeria's border is opened to any information or data coming from any country of the world.

There is data here, before globalization; Nigeria's economy like other developing economies was heavily regulated by the state. Under the regulated economy restrictive business practices on import and export where in place. These include use of import license, imposition of tariffs quota, and control of foreign exchange and sometimes outright bar on importation. During this period, self-reliance was the slogan. However, this has now been replaced by deregulation, economic liberalization and privatization of the national economic activities. The hope is that this new approach will accelerate rapid economic growth and development. Nigeria has now become a big importer of rice to the detriment of locally produced rice. Crystal (I997) most Nigerian prefer American Rice. This has forced the production of local rice to be reduced.

However, Nigeria has become a big import of food. With reduction of subsidies on food in the developed countries, there will be price increase in their food export. This may justify (Raghavan, I999) view that poor countries that rely on food import may face rising import bills, especially when many of the Third world countries suffer from lack of foreign exchange problems. As a consequence the food security of farmers of the Third World countries is threatened. The situation according to (Raghavan, 1997) is made worse by the fact that food decline. According to him between 1987 and I997 food and shipmatts were halved from 12.7 million tons to 5.43 million tons. The impact of increased reliance on food imports undermines a nation's food security and poverty hunger and starvation can only worsen for majority of small farmers.

After many years of globalization indicate will destroy farmers livelihoods displace communities and create rural unemployment otherwise because global trade is also to do with people's livelihood and their most basic social and economic rights. Trade is part of daily life of millions of Nigeria's poor people. Trade is a crucial determinant of the welfare of African and in turn affect their culture. Corbitt (2002) observes that when people social and economic patterns are affected, the culture is over all affected too. Globalization that is built on the unacceptable levels of inequities to vulnerable communities ad groups, or courses global environmental damage and disregards our obligations to future generations is not conclusive to even and sustainable development. Hitherto, the Nigerian culture expects man to provide for the family but this has changed. It is men and women both leave home in search of the available labour it has become a common practice, especially where there are massive retrenchment one will find men at home while the woman goes to work. Hence, it has effect on the household responsibilities, where one finds change of roles when a man has towash, cook and even look after the children.

Many children have dropped out of schools because their families cannot afford to pay their school fees (Obiora , 2002). This situation is reducing the little opportunities they have. There is a limit to one's capacity to enjoy one's right, if one has not gone to school. This means that one may not get a job and therefore one's rights are affected. Irele (200I) notes that there is need to promote, protect, preserve and modernize Black and African culture in general, in order to empower them to 
complete favorably in the emerging global world dominated by western cultural values and standards. One way of doing that is the need to aggressively collect African oral traditions especially poetry, and preserve them with audio-visual facilities in order to conceptualize. Ajayi (200I) remarks that globalization is about competition and struggle for dominance which encourages more than anything else, the continuation and expansion of western imperialism in the new millennium. To make globalization meaningful to Nigerian culture. This is because the cultural order of the day world wise to days is the issue of who you are in terms of knowledge.

\subsection{Sociolinguistics}

While anthropological linguistics and ethno linguistics focus on the relationship between language and some particular aspects of social life and social roles, sociolinguistics is supposed to investigate all aspects of this relationship in the society as a whole. With the starting assumptions that all language events consist of a piece of language in a social context and that every different social context determines a particular form of language (Stockwell, 2002:5) the potential scope of sociolinguistics is enormous. It studies how language is used in a living and complex speech community, from micro sociolinguistic issues dealing with correlations between language variation and use and social groups and situations, to macro sociolinguistic issues such as social attitudes to language, the patterns and needs of national language use, etc. The latter approach, which focuses more on the role of language in society and suggests a greater concern with sociological rather than linguistic explanations, is also known as the sociology of language. One of the key issues here concerns multilingualism and bilingualism, in a social group as well as in an individual speaker, as the most obvious cases of language variation. To the already discussed relation between language and ethnic identity, language rights of minorities, and political factors accompanying these issues, we should add the notions of pidgins and creoles, standard and vernacular languages, language loyalty, diglossia, code switching and code mixing, and language accommodation. They basically refer to various social situations and language behaviors where the speakers are exposed to or forced or willing to use more than one language, or a variety of language or speech.

Some further manifestations of language variation are sometimes less obvious to identify distinctly. They include regional dialects and social dialects, reflecting that in many communities it is possible to tell from a person's speech not only where (s) he comes from but also what class (s)he belongs to, although there seems to be a general tendency that the speech of the higher classes demonstrates less regional variation (cf. Trudgill, I990; Labov, I966, I972, 2001).

Also important is the gender-related language variation, the field of study which has especially flourished in the past couple of decades. There are various ways in which the linguistic behavior of men and women from the same speech community differs - pronunciation, vocabulary, conversational practices, etc. For example, several studies have found that women tend to be more polite, and use more of the standard forms of language, which is frequently explained by their social class awareness, their role in society, or their status in general as a subordinate group (Coates, 1986, 1998; Holmes, I995; Tannen, I996).

While these aspects of the socially relevant language variations focus mostly on language users, their ethnicity, gender, social background, etc., there are some aspects which primarily focus on language use, reflecting particular contexts. The way people talk in court, in school, at business meetings, for instance, is more formal than the relaxed language they use at home or with people they know well. Similar differences are noticeable when we speak to people of a different age or social group. Such language variations are generally known as style, or stylistic differences, although the term register is also used. However, it is better to restrict the latter term to distinctive styles shaped by functional demands of specific situations or occupations - a sports announcer talk, for instance, or a group of specialists, e.g. cardiologists, computer programmers, carpenters, etc., talking about their specialty.

\section{Recommendations}

The major recommendations of the study are as follows:

- Globalization and culture relationship should be institutionalized.

- The constructive cultural actives for the development of human's morality should be spread everywhere basis on the globalization.

- Sociolinguistics fields should be clear and transparent.

- Using of sociolinguistics phenomenon should be regularized in the global cultural activities.

- Creative global-culture relationship with other societal elements should be closer.

\section{Conclusion}

Globalization is firstly determining the cultural practices among the people. Those who are slow are left behind and from indications, everyone seems to be in big rush not to be left behind. Culture of the developed economy has taken over the local culture. Many people of the globe prefer the cultural practices of the developed countries. From the foregoing, it is observed that globalization is characterized by keen competition and an aggressive quest for supremacy by various contending people and interest groups of the world. Ajayi (200I) note that globalization is a continuation and expansion of western imperialism. This 
is because to him, it is a fresh phase n re-colonization of some parties of the world which attempts to continue the promotion of western linguistic heritage and literacy esthetic canons at different languages and literature. For example, the recolonization has imposed on all cultural values on African society and Nigerian culture thereby distorting the African value system and identity. This is achieved by fostering increasing disturbance of the art and culture of Nigerians. Nigerian culture is portrayed as less functional and perhaps inferior to the culture of other people of the world. This is why the people are losing their touch of the natural environment, including the indigenous landscapes, settlement patterns and mode of architecture. According to (Oni, 200I) the performance of African in the emerging scenario would be a function of the ability and commitment of African leaders to mobilize the productive forces of the continent for development. This is because African and its people have through its music made positive impact on the manual sensibilities of the world. He states further that he who controls knowledge dominate the world, since the advance countries controls knowledge that flows to other countries of the world, they benefit more from globalization. However, it must be realized that economic growth without social and cultural justice cannot be the idea of sustainable world development. Development brought by globalization which is arm to eliminating certain culture is not a good conception of development. Globalization should restore peoples dignity, sense of identify continuity and security. In the world of (Marle, I98I) until the philosophy which hold one race superior, and another inferior is finally and permanently discredited and abandoned, there will be no peace anywhere in the world. If as is currently happening globalization according to (Yakubu, 1999) means the ability to one culture to break down other people's competitive capacities or worse, the corrosion of their critical capacities to the point where they lose confidence in themselves. Therefore globalization should not be coded positively and wholesomely.

\section{References}

Campbell, L. (1997). The Sapir-Whorf hypothesis. Retrieved October 4, 2005

Duru Ford L. (2002). The macdonization of Hongkong Global Policy Forum. Radio Northerland.

David F. (2002). Why National Pride Still Has a Home in the Global Village. Global Policy Forum. New York. The Scotsman May 18.

Friday, M. (2002). The Effect of Globalization on Culture in Africa in the Eye of African Woman. Echo. World Council of Churches.

Fagbemi, O. (2002). Educational and Nigeria's Cultural Values. Leading Issues in General Studies; Humanities and Social Sciences.

Gumperz,J.J. (1996). On teaching language in its sociocultural context. In D.I. Slobin, J. Gerhardt, A. Kyratzis, \& J.Guo (Eds.), Social interaction, social context, and language (pp. 469-480). Mahay, New Jersey: Lawrence Erlbaum Associates.

Jean T. (2002). The hidden dimension of globalization: What is at stake geoculturally? Global Policy Forum, New York, ATTAC May 29.

Nishida, H. (1999). A cognitive approach to intercultural communication based on schema theory. International Journal of Intercultural Relations, 23(5), 753-777.

Obiora, A. L. (1996). Feminism, globalization and culture after Beijing Paper presented at a Symposium Organized by Indiana Journal of Global Legal Studies.

Onwioduokit, E. A. \& Ashinze, J.O. (1996). Economic Growth and Foreign Debt; A Case Study of Nigeria. Economic and Financial Review, 34(I),50I - 523.

Oputa, N. C. (1996). ChoTac-Hyon: Foreign Investment in Korea: Recent Trends and Changes to Improve the Investment Environment, Economic and Financial Review, 24(I),54I - 542.

Orunmoluyi, T. P. (2000). Globalization: A Millenium Challenge for Nigerian Banks: The Economist 4 p. 3 I - 32.

O’Neil, D. (1998-2005). Language and culture: An introduction to human communication, Retrieved October I5, 2005 from http://anthro.palomar.edu/ language/ language_6.htm

Peterson, E. \& Coltrane, B. (2003). Culture in second language teaching. Retrieved October II, 2005 from Center for Applied Linguistics

Sapir-Whorf hypothesis. (200I-2005). Retrieved October 8, 2005 from Wikipedia, the free encyclopedia Sapir-Whorf hypothesis: Politics and etiquette. (200I-2005). Retrieved October I0, 2005

Saville-Troike, M. (I997). The ethnographic analysis of communicative events. Chapter II in N. Coupland \& A. Jaworski (Eds.), Sociolinguistics: A reader and a coursebook (pp. I26-I44). New York: St. Martin's Press.

Skoto, B. (1997). Relationship between language and thought from a cross-cultural perspective. Retrieved October II, 2005 from http://www.duke.edu/ pkI0/ language/ca.htm

Stern,H. H.(2009). Fundamental concepts of language teaching. Oxford: Oxford University Press.

Thanasoulas, D. (200I). Radical Pedagogy: The importance of teaching culture in the foreign language classroom. Retrieved October 3, 2005 from the International Consortium for the Advancement of Academic Publication. Retrieved from http://radicalpedagogy.icaap.org/content/ issue3_3/7-thanasoulas.html 
Tuhus-Dubrow R. (2002). World Languages are fast disappearing Global Policy Forum, New York Independent April 25. Wardhaugh, R. (2002). An introduction to sociolinguistics (Fourth Ed.). Oxford: Blackwell Publishers.

Wade, A. (1997). Globalization and itsLimits: Wasington D.C.: Brooking Institution Press.

Yakubu, N. (1999). Millenium and Globalization: What is in it for us? Crystal International News Magazine I o. 6 Abuja Heritage pp. 35.

\section{Copyrights}

Copyright for this article is retained by the author(s), with first publication rights granted to the journal. This is an open-access article distributed under the terms and conditions of the Creative Commons Attribution license (http://creativecommons.org/licenses/by/4.0/). 